\title{
ACID PHOSPHATASE STAINING-PATTERNS IN THE MICROFILARIAE OF ONCHOCERCA VOLVULUS FROM THE GUINEA SAVANNA OF THE JOS PLATEAU, NIGERIA
}

\author{
Gad O. Ufomadu ${ }^{1}$, Eka I. Braide ${ }^{2}$, Gordian O. C. EkeJindu ${ }^{1}$, \\ ISAO TADA ${ }^{3}$, HiRoshi TAKAHASHI ${ }^{4}$ and JoHN I. $\mathrm{AKOH}^{5}$ \\ Received August 13 1986/Accepted October 91986
}

\begin{abstract}
Onchocerca volvulus microfilariae from 130 patients in 8 northern Guinea savanna villages of the Jos Plateau were stained by the naphthol AS-TR-phosphate method for the demonstration of acid phosphatase. Microfilariae were classified into 13 types according to their staining characteristics. Five corresponded to the enzyme types already reported by some workers on the West African rain-forest and Sudan savanna strains of $O$. volvulus. Eight types showed intense enzyme activity in the regions of the amphids and phasmids, in addition to any other structures in microfilaria.

Highly significant variations in type frequency $(\mathrm{p}<0.001)$ were observed between microfilariae from the summit area of the Jos Plateau and those from the villages in the northern area where the Guinea savanna shares common borders with the Sudan savanna.

The multiple enzyme patterns revealed in this study indicate that the $O$. volvulus microfilariae of the Jos Plateau are more polymorphic in relation to enzyme staining than the strains of the parasite from Yemen, Guatemala, Venezuela, and the West African rain-forest and Sudan savanna. A brief background of the study area is given and the significance of these findings is discussed.
\end{abstract}

\section{INTRODUCTION}

It is now well known that the epidemiology and clinical manifestations of human onchocerciasis (river blindness) differ from one endemic region to the other. These differences have been attributed to the existence of geographical strains of Onchocerca volvulus. Duke (1976) recognized 6 strains of the parasite by the ability of the local Simulium vectors to transmit the microfilariae to man and suggested that within the main Onchocerca-Simulium complexes are minor complexes which are not yet clearly recognized but are different in their clinical manifestations and pathogenicity in the local population.

Histochemical method for characterization of microfilariae provides a base for differentiating

1 Parasitology Division, Nigerian Institute for Trypanosomiasis Research, Vom-Jos, Nigeria

2 Present Adress: Department of Biological Sciences, University of Calabar, Calabar, Nigeria

3 Department of Parasitic Diseases, Kumamoto University Medical School, Kumamoto, Japan

4 Japanese Mission, Faculty of Medical Sciences, University of Jos, Nigeria

5 Department of Zoology, University of Jos, Jos, Nigeria

This study was supported by JICA, Japan-Jos University, Nigeria Project (JUJIP No. 7) 
geographical strains of O. volvulus. Omar and Schulz-Key (1976) observed marked differences in the distribution patterns of acid phosphatase in 3 strains of the parasite from West Africa and Guatemala. Yarzabal et al. (1983) showed the similarity in the frequency of the enzyme staining-patterns between the Venezuelan strain and the strains from Guatemala and Yemen, and then observed that these differed from the rain-forest and Sudan savanna strains of West Africa.

Omar (1978) also demonstrated that the proportions of the enzyme patterns in the microfilariae from the West African rain-forest and Sudan savanna, Guatemala and Yemen revealed group differences in each strain. Further, statistically significant differences were observed in the enzyme patterns of microfilarial populations in the rain-forest and Sudan savanna bioclimatic zones of West Africa (Omar et al., 1982). In the work reported here we used the histochemical staining for acid phosphatase to characterize the microfilariae of $O$. volvulus in Jos area of the Guinea savanna in Nigeria.

\section{MATERIALS AND MethodS}

Geography of the study area: The Jos Plateau (1,000-1,500 metres above sea level) in the northern Guinea savanna of Nigeria although located in the tropical zone has a climate similar to the temperate regions. The northern part of this plateau shown on the map (Figure 1) is generally warmer than the summit area (Kuru), and shares borders with the arid Sudan savanna in the neighbouring Bauchi State.

The annual rain-fall $(1,600-2,000 \mathrm{~mm})$ on the Jos Plateau is considerably higher than other areas of northern Nigeria. The rivers that run off these highlands support the breeding of Simulium damnosum s.l. (Crosskey, 1981).

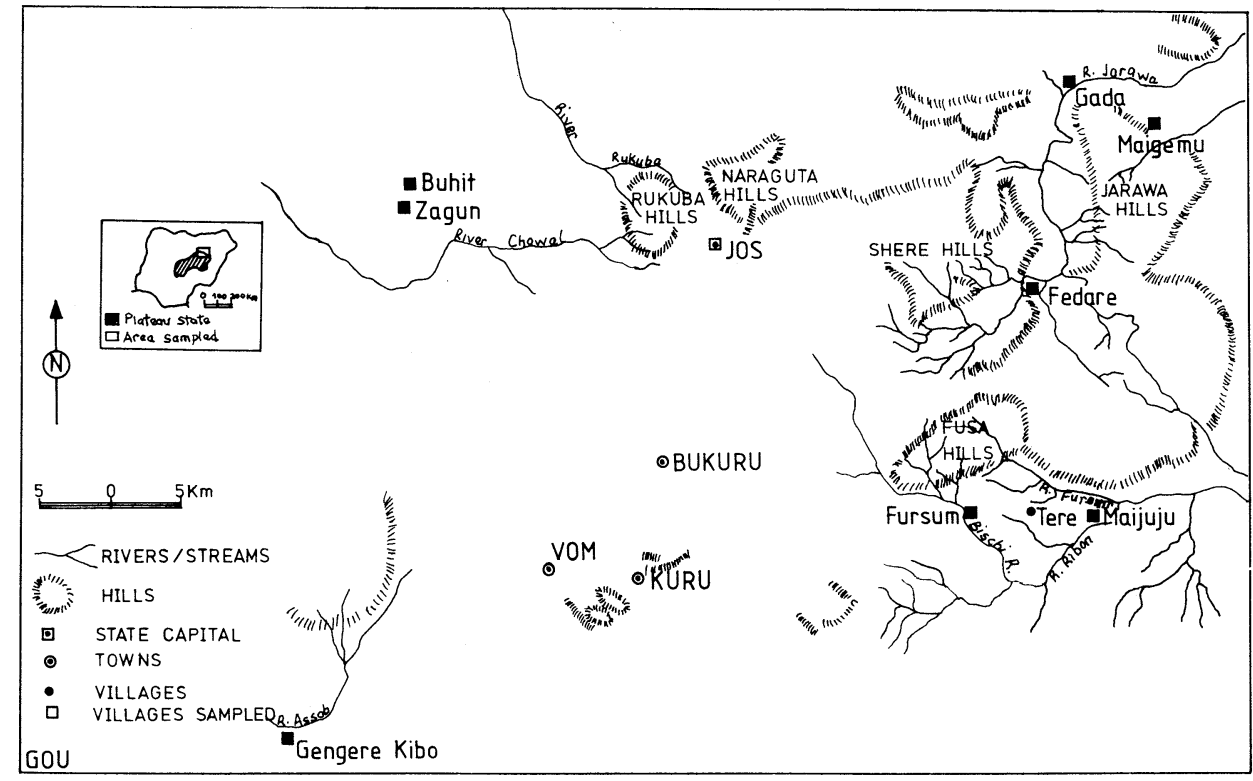

Figure 1 Map of the Jos Plateau showing sample areas (black squares), main rivers, streams and hills. 
Distribution of onchocerciasis: Our epidemiological records show that onchocerciasis is hyperendemic in the villages located in the northern parts and mesoendemic in the summit area (Figure 1). In the hyperendemic villages (Gada and Maigemu), lymphadenopathy, scrotal elephantiasis, hernias and leopard skin are seen in patients. These features are less evident or completely absent in Fedare, Fursum, Maijuju and Gengere Kibo in the summit area. Generally, the prevalence of nodules is low and onchocercal blindness is much reduced in patients when compared with the savanna villages of Burkina Faso.

Collection of microfilariae: O. volvulus microfilariae were obtained from already known carriers of microfilariae by the skin snipping using corneo-scleral punch ( $2 \mathrm{~mm}$ Holth-type; STORTZ Ltd.) at the following locations:
1. Maijuju
$\left(9^{\circ} 45^{\prime} \mathrm{N} \quad 9^{\circ} 10^{\prime} \mathrm{E}\right)$
2. Fursum
$\left(9^{\circ} 34^{\prime} \mathrm{N} \quad 9^{\circ} 06^{\prime} \mathrm{E}\right)$
3. Fedare
$\left(10^{\circ} 54^{\prime} \mathrm{N} \quad 9^{\circ} 07^{\prime} \mathrm{E}\right)$
4. Gengere Kibo
$\left(9^{\circ} 31^{\prime} \mathrm{N} \quad 8^{\circ} 37^{\prime} \mathrm{E}\right)$
5. Gada
$\left(10^{\circ} 02^{\prime} \mathrm{N} \quad 9^{\circ} 07^{\prime} \mathrm{E}\right)$
6. Zagun
$\left(8^{\circ} 42^{\prime} \mathrm{N} \quad 9^{\circ} 58^{\prime} \mathrm{E}\right)$
7. Buhit
$\left(8^{\circ} 45^{\prime} \mathrm{N} \quad 9^{\circ} 59^{\prime} \mathrm{E}\right)$
8. Maigemu
$\left(10^{\circ} 01^{\prime} \mathrm{N} \quad 9^{\circ} 11^{\prime} \mathrm{E}\right)$

Two skin snips were taken between 11.00 and 15.00 hours from the iliac crests of 130 microfilarial carriers and placed in Tyrode solution in flat bottom micro-titre plates. In Maigemu paired snips were taken from the scapulas, iliac crests and lower calves of 40 villagers and microfilariae from each pair were processed separately. The micro-titre wells were carefully covered using cellophane tape and each plate was numbered. Detailed data including clinical manifestations of the disease and opthalmological examination of patients were obtained from our epidemiological records. Samples were immediately transported to our Vom laboratory for processing.

About 3 hours after collection, microfilariae from each micro-titre well were carefully pipetted onto albuminized glass slide, labelled and allowed to dry at room temperature. Each smear was immediately fixed with a few drops of cold $\left(0-4^{\circ} \mathrm{C}\right)$ acetone and again allowed to dry at room temperature. Smears were then placed on hinged flap microscope slide folders, wrapped with cellophane material to exclude moisture and stored in a deep freezer until staining.

Staining of microfilariae: Smears of microfilariae were stained within 2 weeks of collection in incubating medium containing naphthol AS-TR-phosphate (substrate) as described by Chalifoux and Hunt (1971) at $\mathrm{pH} 5.0$ and at $37^{\circ} \mathrm{C}$. Each smear was stained separately in horizontal position for 2 hours by covering slides with the staining medium. The substrate was excluded from the medium used to incubate control slides. All smears were counterstained in methyl green and examined under light microscope for microfilarial acid phosphatase activity. Photomicrographs were then made as required.

Data analysis: The results were analyzed for heterogeneity and significant variations using simple Chi-square test and Friedman's two-way ANOVA by ranks.

\section{REsUlTS}

The various staining patterns: Acid phosphatase activity was observed chiefly in six regions in the microfilariae of $O$. volvulus: the cephalic extremity (amphids area), between amphids and excretory vesicle, excretory vesicle, Inner body area, anal vesicle, and the phasmids in the 


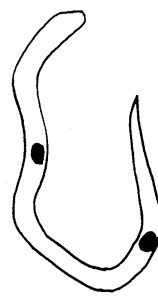

1

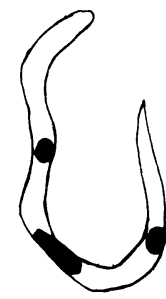

II

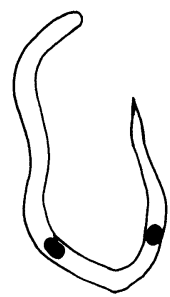

III
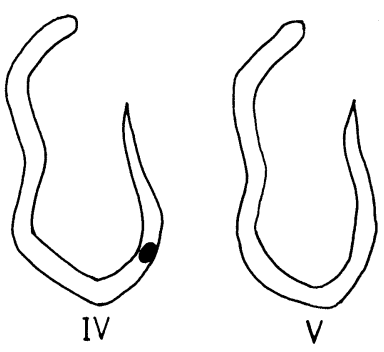

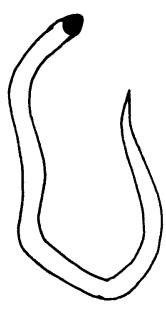

VI

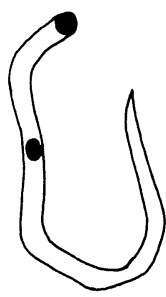

VII

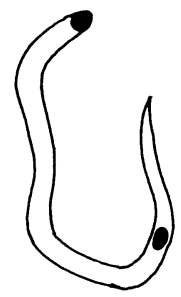

VIII

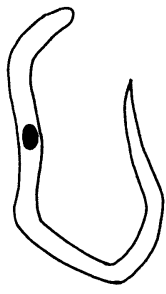

IX

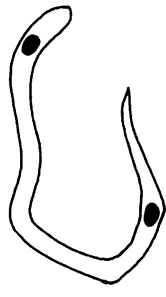

$x$

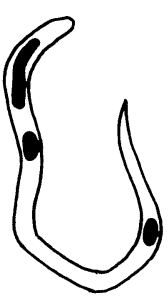

XI

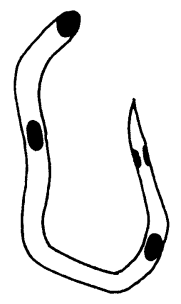

XII

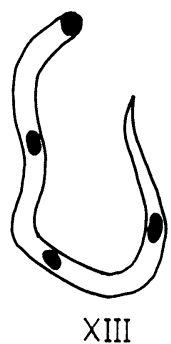

Figure 2 Schematic representation on the 13 acid phosphatase patterns in $O$. volvulus microfilariae.

Figures 3-15 Photomicrographs of the enzyme staining-patterns in O. volvulus microfilariae.

3: Excretory pore/vesicle and anal pore areas (EP+AP).

4: Excretory pore/vesicle and excretory cell, Inner body and anal pore areas (EP+AP).

5: Inner body and anal pore/vesicle areas (IB + AP).

6: Anal pore/vesicle only (AP).

7: Negative staining (NE).

8: Amphids (cephalic) area only (A).

9: Amphids (cephalic) and excretory pore/vesicle areas (A+EP).

10: Amphids (cephalic) and anal pore/vesicle areas (A+AP).

11: Excretory pore/vesicle area only (EP).

12: Between amphids and excretory pore, and anal pore/vesicle area ( $\mathrm{A}-\mathrm{EP}+\mathrm{AP})$.

13: Between amphids and excretory pore/vesicle, excretory pore and anal pore areas (A$\mathrm{EP}+\mathrm{EP}+\mathrm{AP})$.

14: Amphids (cephalic), excretory pore/vesicle, anal pore and phasmids areas $(\mathrm{A}+\mathrm{EP}+\mathrm{AP}+$ P).

15: Amphids (cephalic), excretory pore/vesicle, Inner body and anal pore areas (A+EP+ IB + AP). All magnifications about $\times 600$. 


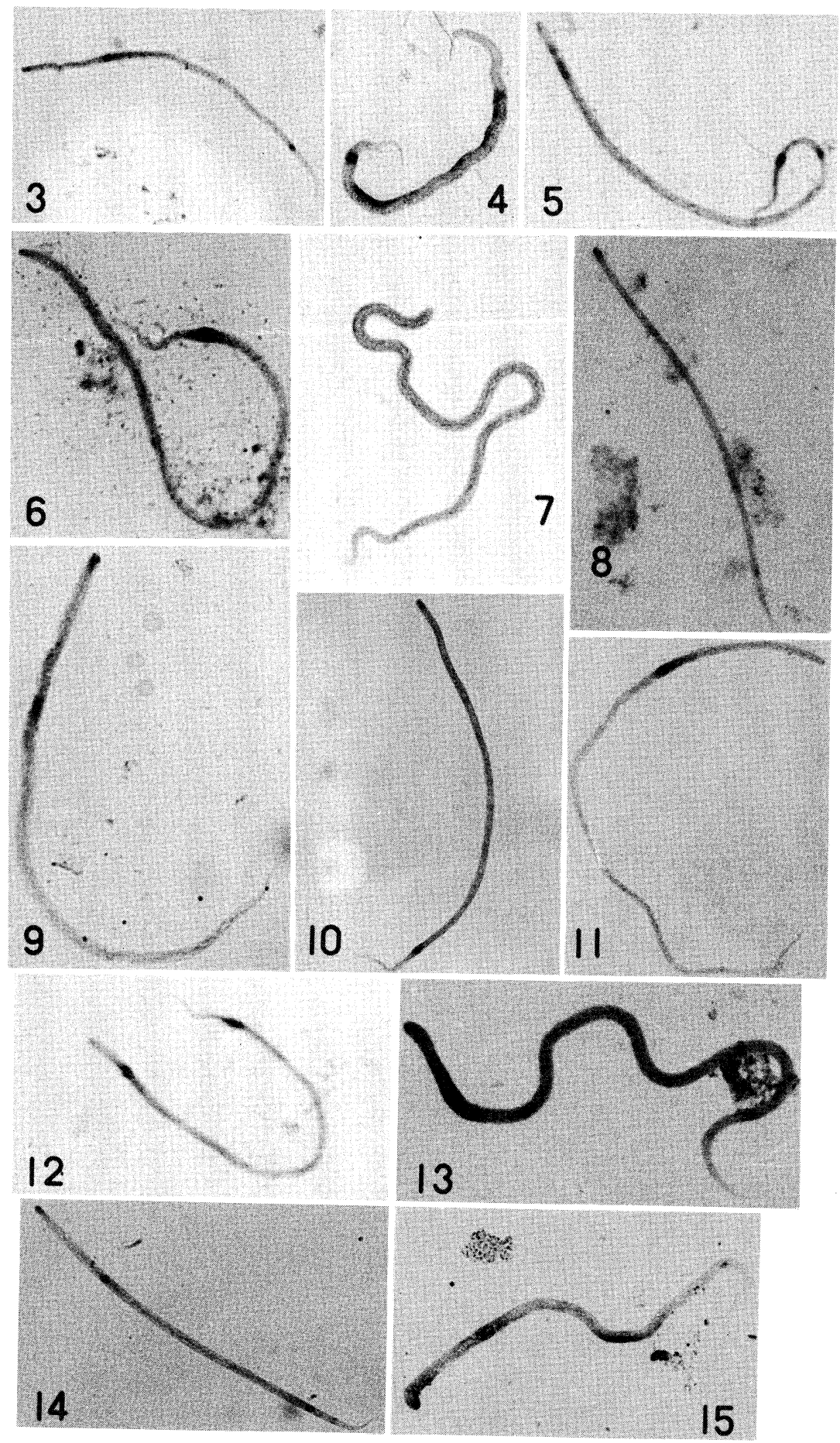


posterior region. We identified 13 enzyme staining-patterns or types according to the presence or absence of acid phosphatase activity in the reactive structures in microfilariae. Five of these corresponded to the staining types reported by Omar (1978) and Omar et al. (1982). The distribution of acid phosphatase in microfilariae as revealed in the 13 patterns was: Type Iexcretory pore/vesicle and anal pore/vesicle areas (EP $+\mathrm{AP})$; Type II-excretory pore/vesicle, Inner body and anal pore (EP + IB + AP); Type III-Inner body and anal pore/vesicle areas (IB + $\mathrm{AP}$ ); Type IV-anal pore/vesicle areas only (AP); Type V-complete negative staining (NE); Type VI-amphids (cephalic) area only (A); Type VII-amphids and excretory pore/vesicle areas (A+ $\mathrm{EP})$; Type VIII-amphids and anal pore/vesicle areas (A+AP); Type IX-excretory pore/vesicle area only (EP); Type $\mathrm{X}$-between amphids and excretory pore/vesicle, and anal pore areas (A-

Table 1 Frequency distribution of the 13 staining patterns

\begin{tabular}{|c|c|c|c|c|c|c|c|}
\hline \multirow{2}{*}{ Village } & \multirow{2}{*}{$\begin{array}{c}\text { No. of } \\
\text { persons } \\
\text { examined }\end{array}$} & \multirow{2}{*}{$\begin{array}{l}\text { Total No. } \\
\text { of mf } \\
\text { examined }\end{array}$} & \multicolumn{5}{|r|}{ Staining } \\
\hline & & & I & II & III & IV & V \\
\hline $\begin{array}{l}\text { Maijuju } \\
\text { and } \\
\text { Fursum }\end{array}$ & 11 & 132 & $19(14.4)^{* *}$ & $0(0.0)$ & $2(1.5)$ & $3(2.3)$ & $16(12.1)$ \\
\hline Fedare & 26 & 455 & $128(28.1)$ & $28(6.2)$ & $5(1.1)$ & $60(13.2)$ & $22(4.8)$ \\
\hline $\begin{array}{l}\text { Gengere } \\
\text { Kibo }\end{array}$ & 4 & 10 & 0 & 0 & 0 & $4(40.0)$ & $2(20.0)$ \\
\hline Gada & 30 & 646 & $52(8.0)$ & $4(0.6)$ & $6(0.9)$ & $330(51.1)$ & $123(19.0)$ \\
\hline $\begin{array}{l}\text { Zagun } \\
\text { and } \\
\text { Buhit }\end{array}$ & 3 & 37 & $21(56.8)$ & 0 & 0 & $6(16.2)$ & $1 \quad(2.7)$ \\
\hline Maigemu & 56 & 3,850 & $943(24.5)$ & $58(1.5)$ & $104(2.7)$ & $563(14.6)$ & $1,278(33.2)$ \\
\hline Total & 130 & 5,130 & $1,163(22.7)$ & $90(1.8)$ & $117(2.3)$ & 966 (18.8) & $1,442(28.1)$ \\
\hline
\end{tabular}

* See the text and Figure 2

** Number of microfilariae (\%)

Table 2 Distribution of acid phosphatase staining

\begin{tabular}{|c|c|c|c|c|c|c|c|}
\hline \multirow{2}{*}{ Village } & \multirow{2}{*}{$\begin{array}{c}\text { No. of } \\
\text { persons } \\
\text { examined }\end{array}$} & \multicolumn{6}{|c|}{ No. of the microfilarial } \\
\hline & & I & II & III & IV & $\mathrm{V}$ & VI \\
\hline $\begin{array}{l}\text { Maijuju } \\
\text { and } \\
\text { Fursum }\end{array}$ & 11 & $5(45.5)^{*}$ & 0 & $2(18.1)$ & $2(18.1)$ & $6(54.6)$ & 0 \\
\hline Fedare & 26 & $20(76.9)$ & $10(38.5)$ & $5(19.2)$ & $14(53.9)$ & $7(26.9)$ & $1 \quad(3.9)$ \\
\hline $\begin{array}{l}\text { Gengere } \\
\text { Kibo }\end{array}$ & 4 & 0 & 0 & 0 & $3(75.0)$ & $2(50.0)$ & 0 \\
\hline Gada & 30 & $10(33.3)$ & $2(6.7)$ & $3(10.0)$ & $22(73.3)$ & $22(73.3)$ & $3(10.0)$ \\
\hline $\begin{array}{l}\text { Zagun } \\
\text { and } \\
\text { Buhit }\end{array}$ & 3 & $1(33.3)$ & 0 & 0 & $2(66.7)$ & $1(33.3)$ & 0 \\
\hline Maigemu & 56 & $39(69.6)$ & $20(35.7)$ & $12(21.4)$ & $39(69.6)$ & $45(80.4)$ & $15(26.8)$ \\
\hline Total & 130 & $75(57.7)$ & $32(24.6)$ & $22(16.9)$ & $82(63.1)$ & $83(63.9)$ & $19(14.6)$ \\
\hline
\end{tabular}

* Number of persons (\%) 
$\mathrm{EP}+\mathrm{AP})$; Type $\mathrm{XI}$-between amphids and excretory pore/vesicle, excretory pore and anal pore areas $(\mathrm{A}-\mathrm{EP}+\mathrm{EP}+\mathrm{AP})$; Type XII-amphids, excretory pore/vesicle, anal pore and phasmids areas $(\mathrm{A}+\mathrm{EP}+\mathrm{AP}+\mathrm{P})$; and Type XIII-amphids, excretory pore/vesicle, Inner body and anal pore areas $(A+E P+I B+A P)$. Figure 2 shows the schematic representation of the assortments of enzyme types according to their staining characteristics in microfilariae. Enzyme activity was revealed in varying degrees of intensity from light/diffuse to intense positivity.

Figures 3-15 show the photomicrographs of acid phosphatase distribution in microfilariae. Most microfilariae stained with greater intensity in the anal and excretory pore areas, in that order, than in other structures. Staining in the cephalic (amphids) area was generally moderate while in the Inner body area enzyme activity appeared as spots or bands especially in the area of

in O. volvulus microfilariae (mf) from the Jos Plateau

\begin{tabular}{|c|c|c|c|c|c|c|c|c|}
\hline \multicolumn{9}{|c|}{ patterns* } \\
\hline VI & VII & VIII & IX & & $\mathrm{X}$ & XI & XII & XIII \\
\hline $0(0.0)$ & $7(5.3)$ & $0(0.0)$ & $11(8.3)$ & 0 & $(0.0)$ & $0(0.0)$ & $56(42.4)$ & $18(13.6)$ \\
\hline $6(1.3)$ & $8(1.8)$ & $8(1.8)$ & $15 \quad(3.3)$ & 2 & $(0.4)$ & $1(0.2)$ & $132(29.0)$ & $40 \quad(8.8)$ \\
\hline 0 & 0 & 0 & 0 & & $(10.0)$ & 0 & $3(30.0)$ & 0 \\
\hline $6(0.9)$ & $3(0.5)$ & $40(6.2)$ & $11(1.7)$ & 9 & $(1.4)$ & $3(0.5)$ & $56 \quad(8.7)$ & $3 \quad(0.5)$ \\
\hline 0 & 0 & 0 & $4(10.8)$ & 0 & & $2(5.4)$ & 1 (2.7) & $2 \quad(5.4)$ \\
\hline $36(3.8)$ & 67 (1.7) & $71(1.8)$ & $102(2.7)$ & 48 & (1.3) & 55 (1.4) & $436(11.3)$ & $89 \quad(2.3)$ \\
\hline $48(0.9)$ & $85(1.7)$ & $119(2.3)$ & $143(2.8)$ & 60 & (1.2) & $61(1.2)$ & 684 (13.3) & $152(3.0)$ \\
\hline
\end{tabular}

patterns of microfilariae from the Jos Plateau

\begin{tabular}{|c|c|c|c|c|c|c|}
\hline VII & VIII & IX & $\mathrm{X}$ & XI & XII & XIII \\
\hline $2(18.1)$ & 0 & $3(27.3)$ & 0 & 0 & $6(54.6)$ & $3(27.3)$ \\
\hline $6(23.1)$ & $4(15.4)$ & $8(30.8)$ & $2(7.7)$ & $1 \quad(3.9)$ & $17(65.4)$ & $8(30.8)$ \\
\hline 0 & 0 & 0 & $1(25.0)$ & 0 & $1(25.0)$ & 0 \\
\hline $2(6.7)$ & 5 (16.7) & $6(20.0)$ & $2 \quad(6.7)$ & $3(10.0)$ & $10(33.3)$ & $3(10.0)$ \\
\hline 0 & 0 & $1(33.3)$ & 0 & $2(66.7)$ & $1(33.3)$ & $2(66.7)$ \\
\hline 22 (39.3) & $24(42.9)$ & $25(44.6)$ & $15(26.8)$ & $17(30.4)$ & $36(64.3)$ & $25(44.6)$ \\
\hline $32(24.6)$ & $33(25.4)$ & $43(33.1)$ & $20(15.4)$ & $23(17.7)$ & $71(54.6)$ & $41(31.5)$ \\
\hline
\end{tabular}


Table 3 Acid phosphatase patterns in O. volvulus microfilariae from

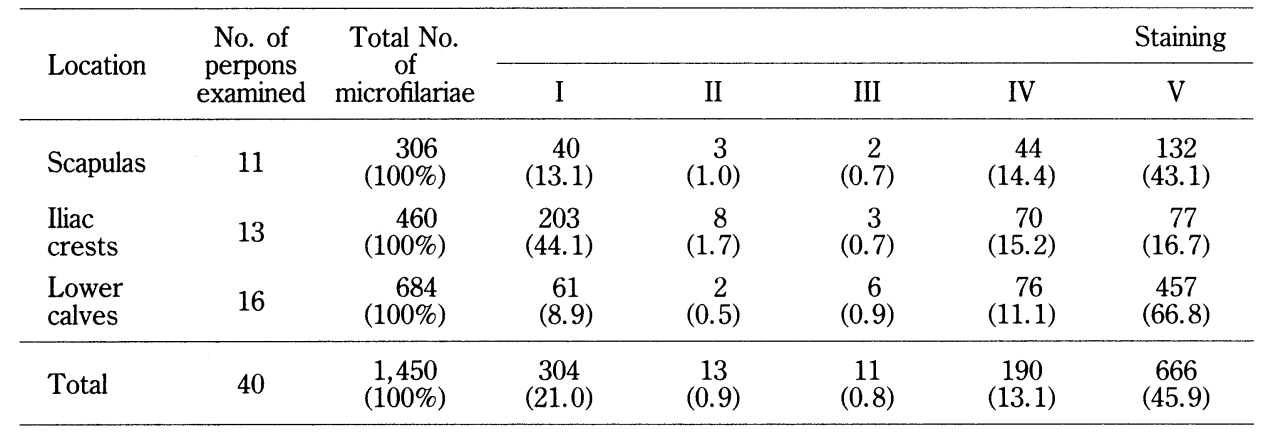

the G-cell (Figures. 4, 5 and 13). In some microfilariae, strong acid phosphatase activity was observed in the cephalic region, and in the excretory pore, and very weak staining in the anal pore, while in others, staining was as in Types VI and IX in microfilariae from the same biopsy. Where there was no staining of microfilariae as in Figure 7 (Type V) (NE), the body walls were clearly delineated. There was occasional staining of the phasmids (Figure 14, Type XII). In very limited samples of microfilariae the phasmids area stained in Types IV and VIII. In Types $\mathrm{X}$ (Figure 12) and XI (Figure 13), the region intermediate between the amphids and the excretory pore stained as spots (Type $\mathrm{X}$ ) or as bands (Type $\mathrm{XI}$ ). Control slides were negative for enzyme activity.

\section{Frequency of patterns}

(i) In microfilariae: The relative frequency of patterns in microfilariae from the 8 villages showed a high degree of heterogeneity and the details are presented in Table 1. Due to the low number of microfilariae from these areas, and the proximity of the villages and similarity of patterns, results from Zagun and Buhit, and Maijuju and Fursum were combined.

From 130 persons, 80 males and 50 females, a total of 5,130 stained microfilariae were examined (an average of 40 parasites per carrier). Four patterns, Types I (EP+AP), IV (AP), $\mathrm{V}(\mathrm{NE})$ and $\mathrm{XII}(\mathrm{A}+\mathrm{EP}+\mathrm{AP}+\mathrm{P})$, occurred more frequently in microfilariae. On the whole, Type V showed the highest frequency (28.1\%) followed by Type I (22.7\%), IV (18.8\%) and XII (13.3\%). Other staining types in our results occurred in low frequency (Table 1).

(ii) In individual microfilarial carriers: The distribution of enzyme patterns or staining types in individuals with microfilariae is shown in Table 2. The variation in frequency of occurrence of the 13 patterns in the 130 patients of the Jos Plateau was not significant $(p>0.01)$. All the 13 patterns were seen concurrently in 3 microfilarial carriers in Gada and in 5 patients in Maigemu. In Fedare and Maijuju areas relatively fewer microfilarial carriers harboured patterns I to XIII. Taken together, 83 microfilarial carriers representing $63.9 \%$ harboured Type V; Type IV in 82 (63.1\%); Type I in 75 (57.7\%); and Type XII in 71 (54.6\%) (Table 3). A significantly higher percentage of Type XII was seen among carriers from Fedare and Maijuju.

(iii) In microfilariae from scapulas, iliac crests and the lower calves: Significant differences $(p<0.001)$ were observed in stained microfilariae from three anatomical positions: scapulas, iliac crests and the lower calves of microfilarial carriers in Maigemu where the heaviest parasitic load was observed in biopsies of carriers. Skin biopsies from the iliac crests contained a significantly 
the scapulas, iliac crests and the lower calves expressed in frequency (\%)

\begin{tabular}{|c|c|c|c|c|c|c|c|}
\hline \multicolumn{8}{|c|}{ patterns } \\
\hline VI & VII & VIII & IX & $\mathrm{X}$ & XI & XII & XIII \\
\hline $\begin{array}{c}7 \\
(2.3)\end{array}$ & $\begin{array}{c}8 \\
(2.6)\end{array}$ & $\begin{array}{c}5 \\
(1.6)\end{array}$ & $\begin{array}{c}13 \\
(4.3)\end{array}$ & $\begin{array}{c}3 \\
(1.0)\end{array}$ & $\begin{array}{c}3 \\
(1.0)\end{array}$ & $\begin{array}{c}34 \\
(11.1)\end{array}$ & $\begin{array}{c}12 \\
(3.9)\end{array}$ \\
\hline $\begin{array}{c}7 \\
(1.5)\end{array}$ & $\begin{array}{c}8 \\
(1.7)\end{array}$ & $\begin{array}{c}5 \\
(1.1)\end{array}$ & $\begin{array}{c}14 \\
(3.0)\end{array}$ & $\begin{array}{c}5 \\
(1.1)\end{array}$ & $\begin{array}{c}2 \\
(0.4)\end{array}$ & $\begin{array}{c}49 \\
(10.7)\end{array}$ & $\begin{array}{c}9 \\
(2.0)\end{array}$ \\
\hline $\begin{array}{c}6 \\
(0.9)\end{array}$ & $\begin{array}{c}10 \\
(1.5)\end{array}$ & $\begin{array}{c}11 \\
(1.6)\end{array}$ & $\begin{array}{c}20 \\
(2.9)\end{array}$ & $\begin{array}{c}4 \\
(0.6)\end{array}$ & $\begin{array}{c}6 \\
(0.9)\end{array}$ & $\begin{array}{c}22 \\
(3.2)\end{array}$ & $\begin{array}{c}3 \\
(0.4)\end{array}$ \\
\hline $\begin{array}{c}20 \\
(1.4)\end{array}$ & $\begin{array}{c}26 \\
(1.8)\end{array}$ & $\begin{array}{c}21 \\
(1.5)\end{array}$ & $\begin{array}{c}47 \\
(3.2)\end{array}$ & $\begin{array}{c}12 \\
(0.8)\end{array}$ & $\begin{array}{c}11 \\
(0.8)\end{array}$ & $\begin{array}{l}105 \\
(7.2)\end{array}$ & $\begin{array}{c}24 \\
(1.7)\end{array}$ \\
\hline
\end{tabular}

higher proportion of Type I (44.1\%) than the other two locations. Similarly, the lower calves harboured a significant number of Type $\mathrm{V}(66.8 \%)$. Within location comparison showed a significantly higher frequency of Type $\mathrm{V}$ in the scapulas and lower calves $(43.1 \%$ and $66.8 \%$, respectively), and Type I (44.1\%) in the iliac crests (Table 3 ).

(iv) In villages and study areas: The frequency of enzyme staining-types in microfilariae among the summit villages (Gengere Kibo, Maijuju, Fursum and Fedare) varied significantly ( $\mathrm{p}$ 0.001). Similar variations were observed in the northern areas (Zagun, Buhit, Gada and Maige$\mathrm{mu}$ ) where the Guinea savanna shares common borders with the Sudan savanna vegetation. Overall variation within and between village groups was highly significant. The distribution of Types I, III, VI, VIII, IX, X and XI did not vary significanlty between village groups; others varied significantly $(\mathrm{p}<0.001)$.

\section{Discussion}

Omar (1978) and Omar et al. (1982) reported 5 acid phosphatase patterns in the microfilariae of $O$. volvulus from the West African rain-forest and Sudan savanna strains of Liberia and Burkina Faso. Braun-Munzinger and Southgate (1977) described 4 patterns in the savanna villages of northern Togo also in West Africa. Four patterns were revealed in each population of microfilariae from the strains of the parasite in Guatemala, Yemen and Venezuela (Omar, 1978; Yarzabal et al., 1983).

Using the same staining method we observed 13 distinct patterns in the sample of $O$. volvulus microfilariae from the northern Guinea savanna of the Jos Plateau in Nigeria. Five (patterns I-V) of the 13 patterns corresponded in staining characteristics to the enzyme types already described in the West African strains in Liberia and Burkina Faso (Omar, 1978). However, our sample differed from the rain-forest and Sudan savanna strains with regard to the frequency of patterns IV and V (Omar et al., 1982). In addition, 8 other patterns (VI-XIII) were revealed in the Jos Plateau microfilariae. A significant proportion (26.4\%) of the microfilariae tested for acid phosphatase in this study demonstrated these additional 8 patterns. The reason of this is that we could for the first time stain cepahlic region (amphids) by the routine technique. The pre-staining condition may have revealed this result or the nature of our microfilariae might be different from the microfilariae with known enzyme activity patterns. If the latter hypothesis was true, we should consider the significance of such variations in $O$. volvulus in this study area in connection with the evolution of this species. 
Patterns VI, VII, VIII, XII and XIII stained in the region of the amphids, in addition to other structures in the microfilaria; the phasmids stained in pattern XII (and occasionally, in patterns IV and VIII in a negligible number of parasites). Until this work, acid phosphatase activity in the amphids and phasmids regions was reported only among blood microfilariae e.g. Loa loa and Dipetalonema perstans (Omar and Kuhlow, 1977). Acid phosphatase activity in these structures suggests that they are metabolically active and may be involved in important functional processes (absorptive, secretory and phagocytic) (Barka, 1962). The amphidial and phasmidial cilia may also function as chemoreceptors in microfilariae (McLaren, 1972).

This histochemical study also demonstrated that the scapular region harboured more microfilariae with patterns V, I and IV and the iliac crests, those with patterns, I, V and IV, while pattern $\mathrm{V}$ can as well be found in relatively greater proportions in the lower calves. From this finding, it may be concluded that the frequency of each pattern is attributable to the anatomical positions of microfilariae which reflect time-lag after migration from the onchocercomata.

It is evident from the foregoing that the microfilariae of $O$. volvulus of the Jos Plateau Guinea savanna are more polymorphic in relation to enzyme staining than the strains of the parasite in Yemen, Guatemala, Venezuela, and the West African rain-forest and Sudan savanna (Omar, 1978; Omar et al., 1982; Omar and Schulz-Key, 1976; Braun-Munzinger and Southgate, 1977; Yarzabal et al., 1983), and may be differentiated as shown by patterns VI-XIII. It is not unlikely that a distinct strain of $O$. volvulus different from the typical Sudan savanna and the rain-forest forms exists on the Jos Plateau.

Highly significant variations were observed in the enzyme patterns in microfilariae notably from the northern and summit villages of the Jos Plateau. Pattern V was predominant in the former and pattern XII in the latter. As was mentioned previously, the Guinea savanna shares common border with the Sudan savanna vegetation in the northern area of the Jos Plateau. Onchocerciasis is severest here with all the clinical manifestations of the typical Sudan savanna form, but, surprisingly, onchocercal blindness is rare in spite of the high intensity of infection in patients. In the summit villages, lymphadenopathy, scrotal elephantiasis, hernias, leopard skin and blindness are relatively fewer (Ufomadu et al. unpublished observation). These discrepancies in the clinical pictures of the disease and the frequency of enzyme patterns from the 2 groups of villages are probably connected with the observation of Duke et al. (1966) in similar zones in the neighbouring Cameroon Republic that the Sudan savanna strain of O. volvulus microfilariae was incompatible with Simulium flies from the Guinea savanna.

\section{ACKNOWLEDGEMENTS}

We are grateful to Mr. Harry Nkwonta (Cartographer) for his assistance in reproducing the map and the Director of the Nigerian Institute for Trypanosomiasis Research for permission to publish our findings.

\section{REFERENCES}

1) Barka, T. (1962): Cellular localization of acid phosphatase activity, J. Histochem. Cytochem., 10, $231-232$

2) Braun-Munzinger, R. A. and Southgate, B. A. (1977): Preliminary studies on the histochemical differentiation of strains of Onchocerca volvulus microfilariae in Togo, Bull. Wld. Hlth. Org., 55, 569575 
3) Chalifoux, B. S. and Hunt, R. D. (1971): Histochemical differentiation of Dirofilaria immitis and Dipetalonema reconditum, J. Am. Vet. Med. Assoc., 158, 601-605

4) Crosskey, R. W. (1981): A review of Simulium damnosum s.l. and human onchocerciasis in Nigeria, with special reference to geographical distribution and the development of a Nigerian National Control Campaign, Tropenmed. Parasit., 32, 2-16

5) Duke, B. O. L. (1976): Strains of Onchocerca volvulus and their pathogenicity, Tropenmed. Parasit., 27, Supplement 21-22

6) Duke, B. O. L., Lewis, D. J. and Moore, P. J. (1966): Onchocerca-Simulium complexes. 1. Transmission of forest and Sudan-savanna strains of Onchocerca volvulus, from various West African bioclimatic zones, Ann. Trop. Med. Parasit., 60, 318-336

7) McLaren, D. J. (1972): Ultrastructural studies on microfilaria (Nematoda; Filariodea), Parasitol., $65,317-332$

8) Omar, M. S. (1978): Histochemical enzyme-staining patterns of Onchocerca volvulus microfilariae and their occurrence in different onchocerciasis areas, Tropenmed. Parasit., 29, 462-472

9) Omar, M. S. and Kuhlow, F. (1977): Localization of acid phosphatase in microfilariae of Loa loa and Dipetalonema perstans from Cameroon, Tropenmed. Parasit., 28, 552-553

10) Omar, M. S., Prost, A. and De C. Marshall, T. F. (1982): Histochemical enzyme variation in Onchocerca volvulus microfilariae from rain-forest and Sudan-savanna areas of the Onchocerciasis Control Programme in West Africa, Bull. Wld. Hlth. Org., 60, 933-944

11) Omar, M. S. and Schulz-Key, H. (1976): Acid phosphatase activity of Onchocerca volvulus microfilariae from West Africa and Guatemala, WHO/ONCHO/76., 130 mimeographed document.

12) Yarzabal, Y., Petralanda, I., Arango, M., Lobo, L. and Botto, C. (1983): Acid phosphatase patterns in microfilariae of Onchocerca volvulus s.l. from the Upper Orinoco Basin, Venezuela, Tropenmed. Parasit., 34, 109-112

$$
\begin{gathered}
\text { ナイジェリア， ジョス高原サバンナ型回旋系状虫仔虫の } \\
\text { 酸性フォスファターゼ・パターン }
\end{gathered}
$$
G. O. Ufomadu ${ }^{1}$ E. I. Braide ${ }^{2}$ G. O. C. Ekejindu ${ }^{1}$ 多田 功 ${ }^{3} \cdot$ 高橋 $\quad$ 弘 $^{4} \cdot \mathrm{J}$. I. $\mathrm{Akoh}^{5}$

昭和 61 年 8 月 13 日 受付/昭和 61 年 10 月 9 日 受理

\footnotetext{
ジョス高原（ギニア型サバンナ） 8 村の130名から得た回旋系状虫仔虫の酸性フォスファターゼ活性 を検討した。その結果，13型のパターンが見出されたが，このうち 5 型は西アフリカの熱帯雨林およ びサバンナですでに報告されたものと一致した。8型はアンフィッドとファスミッドに強い活性を示 した。高地の仔虫と北方スーダン型サバンナに接する地域の仔虫との間にはパターンに差が見出され

今回の研究によりジョス高地の回旋糸状虫仔虫は酸性フォスファターゼ活性において变異が大き く, 他の地域（イエメン, グアテマラ, ベネズエラおよび西アフリカの熱帯雨林, サバンナ地帯）に 比べて著明な差があることが判明した。
} た。

1 ナイジェリア，ジョス市ボム，国立トリパノソーマ研究所寄生虫部門 2 ナイジェリア，カラ バール市, カラバール大学生物学教室 3 熊本大学医学部寄生虫病学教室 4 ナイジェリア, ジョス大学医学部, 日本 JICA チーム 5 ナイジェリア, ジョス大学動物学教室 